OPEN ACCESS

Edited by: Xiaotong Wang,

Ludong University, China

Reviewed by:

Nia M. Whiteley,

Bangor University, United Kingdom

Huaiping Zheng,

Shantou University, China

*Correspondence:

Xiaoting Huang

xthuang@ouc.edu.cn

Specialty section:

This article was submitted to

Aquatic Physiology,

a section of the journal

Frontiers in Physiology

Received: 02 September 2018

Accepted: 31 December 2018

Published: 21 January 2019

Citation:

Liao H, Yang Z, Dou Z, Sun F, Kou S, Zhang Z, Huang $X$ and Bao $Z$ (2019) Impact of Ocean Acidification on the Energy Metabolism and Antioxidant Responses of the

Yesso Scallop (Patinopecten yessoensis). Front. Physiol. 9:1967. doi: 10.3389/fphys.2018.01967

\section{Impact of Ocean Acidification on the Energy Metabolism and Antioxidant Responses of the Yesso Scallop (Patinopecten yessoensis)}

Huan Liao',2, Zujing Yang', Zheng Dou' ${ }^{1}$ Fanhua Sun', Sihua Kou' ${ }^{1}$, Zhengrui Zhang', Xiaoting Huang ${ }^{1 *}$ and Zhenmin Bao ${ }^{1,3}$

'MOE Key Laboratory of Marine Genetics and Breeding, College of Marine Life Sciences, Ocean University of China, Qingdao, China, ${ }^{2}$ College of Animal Biotechnology, Jiangxi Agricultural University, Nanchang, China, ${ }^{3}$ Laboratory for Marine Fisheries Science and Food Production Processes, Qingdao National Laboratory for Marine Science and Technology, Qingdao, China

Ocean acidification (OA), which is caused by increasing levels of dissolved $\mathrm{CO}_{2}$ in the ocean, is a major threat to marine ecosystems. Multiple lines of scientific evidence show that marine bivalves, including scallops, are vulnerable to OA due to their poor capacities to regulate extracellular ions and acid-based status. However, the physiological mechanisms of scallops responding to OA are not well understood. In this study, we evaluated the effects of 45 days of exposure to $\mathrm{OA}(\mathrm{pH} 7.5)$ on the energy metabolism and antioxidant capability of Yesso scallops. Some biochemical markers related to energy metabolism (e.g., content of glycogen and ATP, activity of ATPase, lactate dehydrogenase, glutamate oxaloacetate transaminase, and glutamatepyruvate transaminase), antioxidant capacity (e.g., reactive oxygen species level, activity of superoxide dismutase, and catalase) and cellular damage (e.g., lipid peroxidation level) were measured. Our results demonstrate that the effects of the reduced $\mathrm{pH}$ (7.5) on scallops are varied in different tissues. The energy reserves are mainly accumulated in the adductor muscle and hepatopancreas. Yesso scallops exhibit energy modulation by increasing lactate dehydrogenase activities to stimulate anaerobic metabolism. The highly active $\mathrm{Na}^{+} / \mathrm{K}^{+}$-ATPase and massive ATP consumption in the mantle and gill indicate that a large amount of energy was allocated for the ion regulation process to maintain the acid-base balance in the reduced-pH environment. Moreover, the increase in the reactive oxygen species level and the superoxide dismutase and catalase activities in the gill and adductor muscle, indicate that oxidative stress was induced after longterm exposure to the reduced-pH environment. Our findings indicate that the effects of $\mathrm{OA}$ are tissue-specific, and physiological homeostasis could be modulated through different mechanisms for Yesso scallops.

Keywords: ocean acidification, energy metabolism, oxidative stress, physiological response, scallop

\section{INTRODUCTION}

Increasing amounts of anthropogenic $\mathrm{CO}_{2}$ from the atmosphere dissolved in seawater has changed the overall seawater chemistry with a net increase in hydrogen $\left(\mathrm{H}^{+}\right)$and bicarbonate ions $\left(\mathrm{HCO}_{3}{ }^{-}\right)$ and a decrease in carbonate ions $\left(\mathrm{CO}_{3}{ }^{2-}\right)$, which has already resulted in a 0.1 unit decline in seawater pH since the Industrial Revolution (Caldeira and Wickett, 2003, 2005; Sabine et al., 2004; 
Feely, 2011; Perez et al., 2018). These changes are known as ocean acidification (OA). According to the prediction of the Intergovernmental Panel on Climate Change (IPCC), the $\mathrm{pH}$ of surface seawater could further decrease to 7.8 and 7.4 by the years 2100 and 2300, respectively (Caldeira and Wickett, 2003; Stocker, 2013). Many studies have confirmed that the predicted changes of seawater $\mathrm{pH}$ will have widespread negative effects on the structure, function and fitness of marine ecosystems (Feely, 2011; Uthicke et al., 2013). The variety of responses within and between taxa suggest that $\mathrm{OA}$ is a driver for substantial change in ocean ecosystems this century, potentially leading to longterm shifts in species composition (Pörtner and Farrell, 2008; Wittmann and Pörtner, 2013). As a result, understanding the potentials of maintaining physiological homeostasis will help predict biological stability and changes to rapid anthropogenic modifications of ecosystems and geosystems (Somero, 2010; Applebaum et al., 2014).

Marine bivalves, such as oyster, mussel, clam and scallop, are widely distributed, and they are economically and ecologically important (Gazeau et al., 2013; Kroeker et al., 2013). Scientific literature has revealed that most mollusk species are vulnerable to OA (Pörtner and Farrell, 2008; Wittmann and Pörtner, 2013). To regulate physiological homeostasis, energy is required in response to the environmental changes. Metabolic energy demands under acidification stress may exceed the energy supply from food or/and accrued energy resources, which might lead to a lack of adenosine triphosphate (ATP) to sustain routine metabolism (Lannig et al., 2010). However, some mollusks, such as bivalve fingernail clam Sphaerium occidentale and the cephalopod Nautilus pompilius, can overwhelm the capacity of systemic functions or inhibit the metabolic rate to conserve energy and to extend the survival time (Guppy, 1999). Recent studies have shown that modest increases in dissolved $\mathrm{CO}_{2}(<1200 \mu \mathrm{atm})$ have little effect on metabolic rates, whereas extremely high levels of dissolved $\mathrm{CO}_{2}$ (>5000 $\left.\mu \mathrm{atm}\right)$ could depress metabolic rates (Michaelidis et al., 2005; Beniash et al., 2010; Hendriks et al., 2010; Thomsen and Melzner, 2010; Zhao et al., 2017b). As shown by Cao et al. (2018), Pacific oyster (Crassostrea gigas) modulates energy sources by inhibiting aerobic energy metabolism, stimulating anaerobic metabolism, and increasing glycolytic enzyme activity following exposure to a reduced $\mathrm{pH}$ value of 7.6 for 28 days. The clams (Ruditapes philippinarum) were reported to be able to maintain/regulate their physiological status and biochemical performance under reduced $\mathrm{pH}$ (7.3) for 28 days (Velez et al., 2016). However, in blue mussel Mytilus edulis, energy and protein metabolism were strongly affected by elevated $p \mathrm{CO}_{2}(1,120,2,400$, or $4,000 \mu$ atm after 2 months of treatment) (Hüning et al., 2013). In addition, some recent transcriptomic analyses have indicated that marine bivalves implement a compensatory acid-base mechanism, metabolic depression and positive physiological responses to mitigate the effects of OA (Goncalves et al., 2016, 2017a,b; Li et al., 2016a,b; Peng et al., 2017).

Oxidative stress, the production and accumulation of reactive oxygen species (ROS), is an important component of the stress response for marine organism when exposed to environmental change (Lesser, 2006). In response to oxidative stress, a wide set of antioxidant systems including superoxide dismutase (SOD) and catalase (CAT) have evolved in marine organisms (Lesser, 2006). The oxidative stress response is prevalent in marine bivalves when exposed to elevated $\mathrm{CO}_{2}$ levels. As shown in the mussel $M$. galloprovincialis, the oxidative status was negatively affected by reduced $\mathrm{pH}$ with an increase in antioxidant enzymes activity and ROS overproduction (Freitas et al., 2017). In the mussel $M$. coruscus, most biochemical indexes [SOD, CAT, glutathione peroxidase $(\mathrm{GPx})$, acid phosphatase (ACP), and alkaline phosphatase (ALP)] measured in gills and hemocytes were increased when the mussels were subjected to reduced $\mathrm{pH}$ (Huang et al., 2018). Nevertheless, no persistent oxidative stress signal was observed during long-term (8-15 weeks) exposure to moderately elevated $\mathrm{CO}_{2}\left(\sim 800 \mathrm{ppm} \mathrm{CO}_{2}\right)$ in hard shell clam Mercenaria mercenaria and eastern oyster C. virginica (Matoo et al., 2013). In addition, some studies have demonstrated that the key target genes associated with antioxidant defenses (ecSOD, catalase, and peroxiredoxin 6) were susceptible to OA in marine bivalves (Goncalves et al., 2016, 2017a,b; Li et al., 2016a,b; Wang et al., 2016).

All of these studies indicated that the metabolic effects and antioxidant responses varied among different marine species under elevated dissolved $\mathrm{CO}_{2}$ seawater (Dupont et al., 2010; Hendriks et al., 2010; Kroeker et al., 2010). However, there was very limited information about the effects of OA on scallops (Benedetti et al., 2016; Haider et al., 2016; Nardi et al., 2018). The Yesso scallop (Patinopecten yessoensis) is an economically important shellfish in China, and the production is approximately 240,000 tons in 2016 (data from 2017 China Fishery Statistical Yearbook). The present study aimed to systematically assess the metabolic effects and antioxidant responses of Yesso scallops under present and future predicted sea surface $\mathrm{pH}$. After 45 days of exposure to two $\mathrm{pH}$ levels (8.0 and 7.5), we measured some biochemical markers to determine the energy metabolism levels [assessed by the activity of ATPase, lactate dehydrogenase (LDH), glutamate oxaloacetate transaminase (GOT) and glutamate-pyruvate transaminase (GPT), content of glycogen (GLY) and ATP]; antioxidant capacity (ROS, CAT, and SOD); and cellular damage [measured by the lipid peroxidation (LPO) level] of four tissues (adductor muscle, mantle, gill, and hepatopancreas). The findings of the current study can improve our understanding of the physiological mechanisms involved in regulating energy metabolism and antioxidant responses in marine bivalves when exposed to elevated $\mathrm{CO}_{2}$ levels.

\section{MATERIALS AND METHODS}

\section{Experimental Animals Collection and Acclimation}

Samples of 2-year-old Yesso scallops were collected from Haiyi Seeds Co., LTD, in Shandong province, China, in September 2017. The scallops without shell damage were transported on ice to the laboratory and acclimated for 1 week in a recirculated aquarium system equipped with a filtering system ( $\mathrm{pH} 8.0$, temperature $18^{\circ} \mathrm{C}$, and salinity $30.2 \%$ ). During the acclimation period, all 
scallops were fed twice daily with Nitzschia closterium (40,000 cells /animal), and the seawater was changed daily.

\section{Ocean Acidification Stimulation and Seawater Chemistry Analysis}

After 1 week of acclimation, the healthy scallops were randomly divided into two groups and placed in two different environments: the control group at a $\mathrm{pH}$ of 8.0 (current concentration of $p \mathrm{CO}_{2}$ ) and the experimental group at a $\mathrm{pH}$ of 7.5 (representing the predicted water surface $\mathrm{pH}$ level of the twenty-first century) (Caldeira and Wickett, 2003; Stocker, 2013). For each treatment, there were three replicates of $\sim 50$ - L tanks, holding ten scallops each. The reduced $\mathrm{pH}$ value $(\mathrm{pH}$ 7.5) was maintained by vigorously bubbling ambient air or a $\mathrm{CO}_{2}$ gas mixture. The $\mathrm{CO}_{2}$ gas mixture was obtained by mixing $\mathrm{CO}_{2}$-free air and pure $\mathrm{CO}_{2}$ gas at known flow rates using flow controllers (Zhao et al., 2017a). The pH of seawater was monitored using a $\mathrm{pH}$ meter (Sartorius PB-10) to ensure no substantial change in $\mathrm{pH}$ during the experiment. The other seawater parameters including salinity, temperature and dissolved oxygen (DO) were measured daily by a multi-parameter water quality meter (HORIBA U-52, Japan). The total alkalinity (TA) was monitored once a week by potentiometric titration (Anderson and Robinson, 1946). The carbonate system parameters were calculated using CO2SYS software (Pierrot et al., 2006), and the seawater parameters for the experimental exposures are given in Table 1.

\section{Biochemical Assays}

After 45 days of experiments, six scallops per treatment were collected at random. Four tissues, including the adductor muscle, mantle, gill and hepatopancreas were collected from each specimen and stored at $-80^{\circ} \mathrm{C}$ until further analyses. For GLY content determination, the tissues were added to an alkaline solution (1:3, w:v) in boiling water for $20 \mathrm{~min}$, aiming to destroy all components except GLY. For the remaining biochemical markers, the tissues were added to an ice-cold physiological saline solution (1:9, w:v) and homogenized by ultrasonic treatment $\left(0^{\circ} \mathrm{C}, 360 \mathrm{Watt}\right)$. The homogenization was then centrifuged for $10 \mathrm{~min}$ at $2500 \mathrm{rpm}$ and $4^{\circ} \mathrm{C}$. The supernatants were stored at $-80^{\circ} \mathrm{C}$ or immediately used to determine the content of ROS and ATP, the LPO levels, and the activities of SOD, CAT, GOT, GPT, $\mathrm{LDH}$, and ATPase.

All of the enzymatic activities and biochemical assays were analyzed following the instructions of kits from the Nanjing
Jiancheng Bioengineering Institute. Optical density values were measured using a microplate reader (Infinite 200 pro, Tecan). The results of the enzymatic activities were expressed as the unit per gram or unit per milligram of protein (U/g or U/mg protein).

Reactive oxygen species production was quantified using 2,7dichlorofluorescin diacetate (DCFH-DA) treatment (Eruslanov and Kusmartsev, 2010). DCFH-DA is a non-polar dye, and it is converted into the polar derivative DCFH by cellular esterases that are non-fluorescent but would be oxidized by ROS to form highly fluorescent DCF (Burow and Valet, 1987). The fluorescence intensity was positively correlated with the ROS content, which was measured at the excitation and emission wavelengths of 500 and $530 \mathrm{~nm}$, respectively. The results were referred to the standard curve drawn by positive control of the reactive oxygen donor with gradient concentrations.

The LPO levels were determined by measuring malondialdehyde (MDA). The quantitative measurement of MDA was based on the reaction of MDA and thiobarbituric acid (TBA). The reaction product MDA-TBA2 was measured at $532 \mathrm{~nm}$ (Janero, 1990).

The SOD activity was measured by the WBT-1 method (Peskin and Winterbourn, 2000). The tetrazolium salt WST-1 was converted into water-soluble WST-1 formazan by a superoxide radical generated by the conversion of xanthine to uric acid and hydrogen peroxide $\left(\mathrm{H}_{2} \mathrm{O}_{2}\right)$ by xanthine oxidase. Meanwhile, the existence of SOD reduced the concentrations of the superoxide anion radical and thereby lowered the formation rate of WST-1. The absorbance of the final product was measured at $450 \mathrm{~nm}$ after $20 \mathrm{~min}$ of incubation at $37^{\circ} \mathrm{C}$. The results are expressed in unit per milligram of protein ( $\mathrm{U} / \mathrm{mg}$ protein). One unit of SOD activity corresponded to the enzyme quantity when the SOD inhibition rate reached $50 \%$ under the assay conditions.

The CAT activity was determined on the basis of the ammonium molybdate method (Góth, 1991). CAT acted on catalyzing the $\mathrm{H}_{2} \mathrm{O}_{2}$ degradation reaction, which was terminated by adding ammonium molybdate. Moreover, ammonium molybdate and $\mathrm{H}_{2} \mathrm{O}_{2}$ reacted rapidly in forming a yellow complex, which was measured at $405 \mathrm{~nm}$. One unit of CAT activity was defined as the degradation of $1 \mu \mathrm{mol} \mathrm{H}_{2} \mathrm{O}_{2}$ per second per milligram of tissue protein.

The GLY content was quantified according to the anthrone colorimetric method (Carroll et al., 1956). After treatment in concentrated sulfuric acid, GLY dehydrated and produced glycolaldehyde. Subsequently, the production was reacted with anthrone and formed blue compounds, which contained a maximum absorption peak at a wavelength of $620 \mathrm{~nm}$.

TABLE 1 | Water chemistry parameters during 45 days of incubation of $P$. yessoensis.

\begin{tabular}{|c|c|c|c|c|c|c|c|}
\hline Treatment & \multicolumn{4}{|c|}{ Measured parameters } & \multicolumn{3}{|c|}{ Calculated parameters } \\
\hline Control & $8.01 \pm 0.02$ & $18.35 \pm 0.21$ & $30.27 \pm 0.25$ & $2282.67 \pm 149.70$ & $546.66 \pm 71.81$ & $3.5 \pm 0.33$ & $2.17 \pm 0.21$ \\
\hline $\mathrm{CO}_{2}$-incubation & $7.51 \pm 0.01$ & $18.66 \pm 0.30$ & $30.47 \pm 0.17$ & $2260.1 \pm 66.10$ & $2217.91 \pm 87.75$ & $1.16 \pm 0.06$ & $0.72 \pm 0.03$ \\
\hline
\end{tabular}

$\mathrm{pH}_{\mathrm{NBS}}, \mathrm{pH}$ calibrated with National Bureau of Standard scale; T, temperature; Sal, salinity; TA, total alkalinity; $\mathrm{pCO}_{2}$, partial pressure of $\mathrm{CO}_{2}$; $\Omega \mathrm{C}$ and $\Omega a$, saturation state of calcite and aragonite, respectively. Data are presented as the means \pm standard deviations. 
The LDH activity was measured by the trace enzyme labeling method (Weeks and Johnson, 1977), which is based on the function of $\mathrm{LDH}$ in catalyzing the formation of pyruvate. The pyruvate was reacted with 2, 4-dinitrophenylhydrazine in a terminal indicator reaction to form the characteristic brown color of the corresponding 2, 4-dinitrophenylhydrazone pyruvate, which was measured colorimetrically at $440 \mathrm{~nm}$. One unit of LDH activity was defined as the formation of $1 \mu \mathrm{mol}$ pyruvate per 15 min per gram protein.

The ATP content was determined according to the phosphomolybdic acid colorimetry method (Chen and Sun, 2002). It is an indirect method for determining the ATP level. In brief, creatine kinase was added to catalyze the formation of phosphocreatine from ATP and creatine, and then the product was detected at $636 \mathrm{~nm}$.

The ATPase activity was quantified following the protocol of the ATP enzyme test kit $\left(\mathrm{Na}^{+} / \mathrm{K}^{+}\right.$-ATPase and $\mathrm{Ca}^{2+} / \mathrm{Mg}^{2+}$ ATPase) from Nanjing Jiancheng Bioengineering Institute, which was based on ATPase function in decomposing ATP to produce ADP and inorganic phosphorus. The activity of ATPase was judged by the amount of inorganic phosphorus, which was interacted with a phosphorus-fixing agent for $30 \mathrm{~min}$ at $37^{\circ} \mathrm{C}$. The absorbance was measured at $660 \mathrm{~nm}$ when the product cooled to room temperature, and one unit of ATPase was defined as the product of $1 \mu \mathrm{mol}$ inorganic phosphorus per hour per milligram of protein.

The GPT and GOT activities were quantified following the method of Reitman and Frankel (1957). The activity of GPT or GOT was measured by mixing tissue suspension with the corresponding substrate. Both enzymes were acted on catalyzing the transamination of substrate and the formation of pyruvate. After a 30 -min interaction at $37^{\circ} \mathrm{C}, 2$, 4-dinitrophenylhydrazine solution was added to stop the transamination and reacted with pyruvate for $20 \mathrm{~min}$ at $37^{\circ} \mathrm{C}$. Subsequently, the reaction liquid was mixed with $\mathrm{NaOH}$ solution for $15 \mathrm{~min}$ at room temperature. The optical density was read at $505 \mathrm{~nm}$. The results were referred to the standard curve drawn by the pyruvate standard solution with gradient concentrations and expressed in unit per gram of protein.

\section{Statistical Analysis}

The statistical analyses of the data were preformed using SPSS software (version 20.0). The data collected from this study are expressed as the means \pm standard deviation $(N=6)$. A one-way analysis of variance (ANOVA) and Tukey's test were used to differentiate between the means. Tests were considered significant at $p<0.05$.

\section{RESULTS}

The levels of ROS, LPO, SOD and CAT in the adductor muscles, mantles, gills and hepatopancreas of scallops exposed to reduced$\mathrm{pH}$ seawater and ordinary seawater (control) are illustrated in Figure 1. The levels of ROS in all tested organs were generally higher in the scallops exposed to reduced-pH seawater compared with the control group. The results of the statistical analyses demonstrate that the ROS levels in the gills and hepatopancreas were significantly higher $(p<0.05)$ in the scallops exposed to reduced-pH seawater than in the control group. For the LPO levels, no significant difference $(p>0.05)$ was observed in all organs between the scallops exposed to reduced-pH seawater and the control group. The SOD activities in the adductor muscles and hepatopancreas were significantly higher $(p<0.05)$ in the scallops exposed to reduced-pH seawater than in the control group. However, the SOD activities in the gills was significantly lower $(p<0.05)$ in the scallops exposed to reduced$\mathrm{pH}$ seawater $\left(6.19 \pm 0.46 \mathrm{U}_{\text {mgprot }^{-1}}\right)$ than in the control group $\left(130.06 \pm 33.73 \mathrm{U} \mathrm{mgprot}^{-1}\right)$. For the CAT activities, the scallops exposed to reduced-pH seawater demonstrated significantly higher $(p<0.05)$ CAT activity in the adductor muscles (99.96 $\pm 36.95 \mathrm{U}$ mgprot $^{-1}$ ) compared with the scallops in the control group $\left(14.58 \pm 2.80 \mathrm{U} \mathrm{mgprot}^{-1}\right)$.

The effects of reduced $\mathrm{pH}$ on different types of ATPase were varied in the four tissues (Figures 2A,B). The activities of $\mathrm{Na}^{+} / \mathrm{K}^{+}$-ATPase in the mantles and gills of the scallops exposed to reduced-pH seawater were significantly higher $(p<0.05)$ than in the respective organs of the scallops in the control group. The $\mathrm{Ca}^{2+} / \mathrm{Mg}^{2+}$-ATPase activity in the gills of the scallops exposed to reduced-pH seawater $\left(5.13 \pm 0.39 \mu\right.$ molPi mgprot $\left.^{-1} \mathrm{~h}^{-1}\right)$ were significantly lower $(p<0.05)$ than in the gills of the scallops in the control group $\left(7.98 \pm 0.42 \mu\right.$ molPi $\left._{\text {mgprot }}{ }^{-1} \mathrm{~h}^{-1}\right)$. For ATP contents, the scallops exposed to reduced-pH seawater demonstrated significantly lower $(p<0.05)$ ATP contents in the mantles $\left(168.13 \pm 52.79 \mu \mathrm{mol}_{\text {gprot }}{ }^{-1}\right)$ compared with the scallops in the control group $\left(483.86 \pm 91.41 \mu \mathrm{mol}\right.$ gprot $\left.^{-1}\right)$ (Figure 2C).

The results of the statistical analyses demonstrated that the GLY content in the adductor muscles was significantly lower $(p<0.05)$ in the scallops exposed to reduced-pH seawater (2.06 $\left.\pm 0.52 \mathrm{mg} \mathrm{g}^{-1}\right)$ compared with the control group $\left(4.32 \pm 0.53 \mathrm{mg} \mathrm{g}^{-1}\right)$. However, the GLY content in the hepatopancreas was significantly higher $(p<0.05)$ in the scallops exposed to reduced-pH seawater $\left(5.70 \pm 0.38 \mathrm{mg} \mathrm{g}^{-1}\right)$ compared with the control group (4.58 $\left.\pm 0.09 \mathrm{mg} \mathrm{g}^{-1}\right)$ (Figure 3A). The LDH activities in the adductor muscles of the scallops exposed to reduced-pH seawater $\left(1565.31 \pm 0.01 \mathrm{U}_{\text {gprot }^{-1}}\right)$ were significantly higher $(p<0.05)$ than in the adductor muscles of the scallops in the control group $\left(861.53 \pm 134.71 \mathrm{U}_{\text {gprot }^{-1}}\right)$ (Figure 3B).

For the GOT and GPT activities, no significant difference $(p>0.05)$ was observed in the adductor muscles, mantles and gills between the scallops exposed to reduced-pH seawater and the control group. However, the GPT activity in the hepatopancreas was significantly lower $(p<0.05)$ in the scallops exposed to reduced-pH seawater $\left(5227.44 \pm 817.48 \mathrm{U}_{\text {gprot }^{-1}}\right)$ compared with the control group $\left(8294.14 \pm 628.25 \mathrm{U}_{\text {gprot }^{-1}}\right)$ (Figure 4).

\section{DISCUSSION}

Ocean acidification caused by increased $\mathrm{CO}_{2}$ emission to the atmosphere has been showed in all areas of the ocean including 

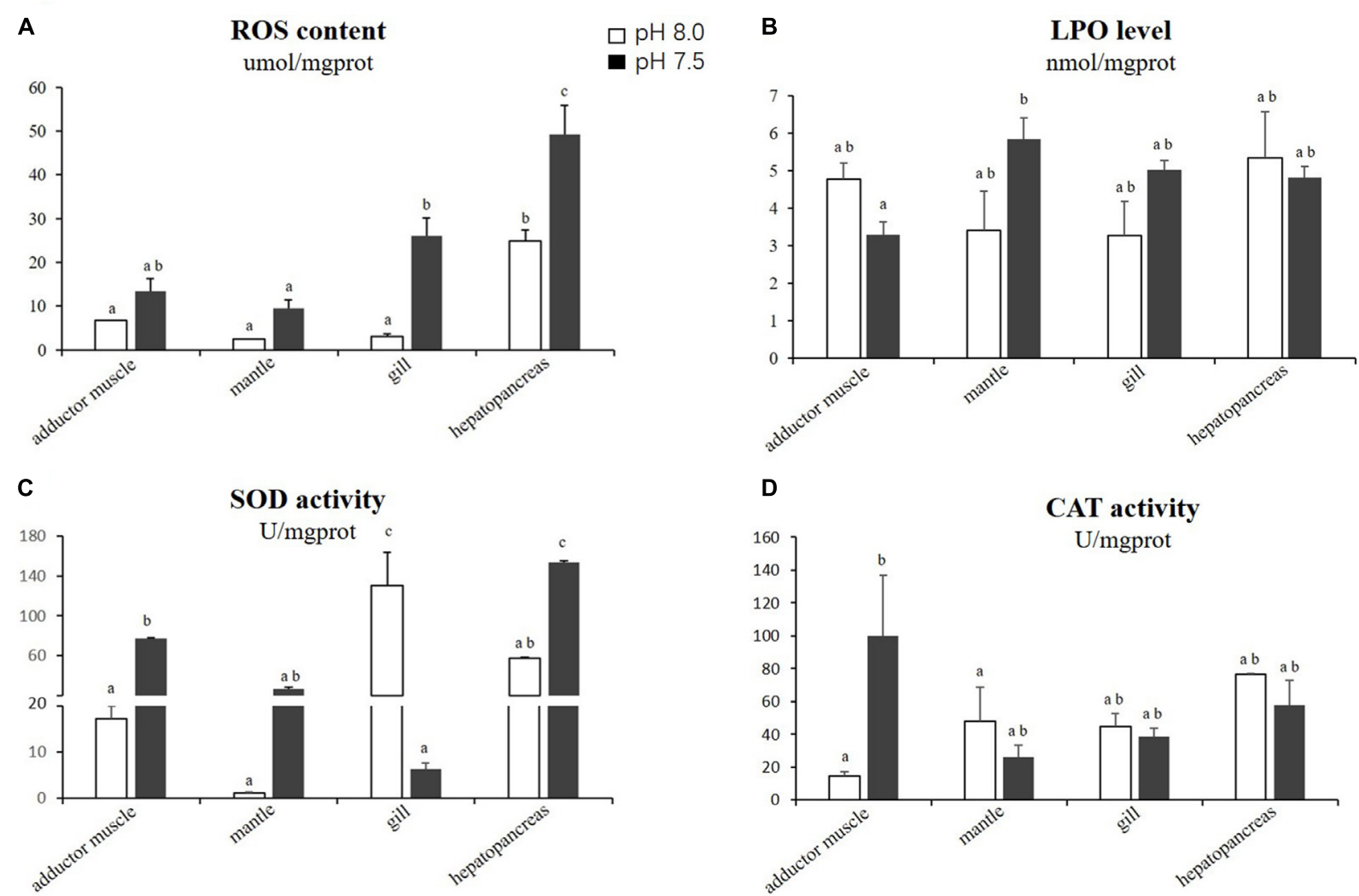

FIGURE 1 | Oxidative stress-related parameters in four tissues of $P$. yessoensis exposed to different pH levels (7.5 and 8.0). (A) ROS. (B) LPO. (C) SOD. (D) CAT. Each bar represents the means \pm standard deviations $(n=6)$. Different letters indicate significant differences among different treatments $(p<0.05)$.

deep sea and coastal waters (Orr et al., 2005; Wittmann and Pörtner, 2013). The impacts of OA are more substantial in coastal waters, where the ecosystem responses to OA could have the most severe implications for mankind (Doney et al., 2007; Feely et al., 2008, 2009, 2010; Wootton et al., 2008; Zhai et al., 2012). Coastal organisms show diverse responses to elevated seawater $\mathrm{pCO}_{2}$ (Pörtner and Farrell, 2008; Ries et al., 2009; Hendriks et al., 2010; Wittmann and Pörtner, 2013). The Yesso scallop is an economically important marine shellfish. This species has long been cultivated in the coastal ocean of China, Japan, and Russia (Shumway and Parsons, 2006). However, the potential effects of OA on the physiology of Yesso scallop is still unknown. Thus, the current study aims to evaluate the effects of OA on the scallop based on physiological and biochemical markers.

As a major form of energy storage in cells, GLY supplies energy quickly through glycolysis and oxidative phosphorylation. Adequate glycogen storage in muscle is important to support the optimal movement of muscle (Jensen and Richter, 2012). In the current study, low $\mathrm{pH}$ stress resulted in a decrease in glycogen level but an increase in LDH activity in the adductor muscles of scallops. A similar observation has been reported in C. gigas, where the GLY level in muscle tissue decreased after exposure to low pH seawater (Lannig et al., 2010). On the other hand, under stressful environments, $\mathrm{LDH}$ is an important enzyme that accelerates ATP production through anaerobic processes to maintain energy homeostasis (Strahl et al., 2011). The combined effects of elevated LDH activity and decreased GLY level in muscle tissues suggest that $\mathrm{OA}$ accelerates glycolysis, which might be an energy strategy of the Yesso scallop to fuel the high energy demand. The hepatopancreas is another important energy storage organ, and it plays an important role in energy homeostasis of the blood circulation system (Barber and Blake, 1985). The rising in GLY content in the hepatopancreas of the Yesso scallop during reduced-pH exposure suggests that some of the lactic acids from the muscle tissues entered the hepatopancreas through the blood circulation system, where they were then resynthesized to GLY for energetic conservation.

The transaminase GPT plays a key role in mobilizing L-amino acids for gluconeogenesis, and it acts as a link between carbohydrate and protein metabolism under altered physiological, pathological, and induced environmental stress conditions (Ramaswamy et al., 2015). However, the influences of acidification on GPT activity varies by species. A study on the thick shell mussel $M$. coruscus found that the activity of GPT in the gill and digestive gland increased when exposed to reduced-pH seawater ( $\mathrm{Hu}$ et al., 2015). The current study recorded a contradictory result, where the GPT activity decreased in $P$. yessoensis under the reduced-pH treatment. The hepatopancreas is a major organ for gluconeogenesis. The 


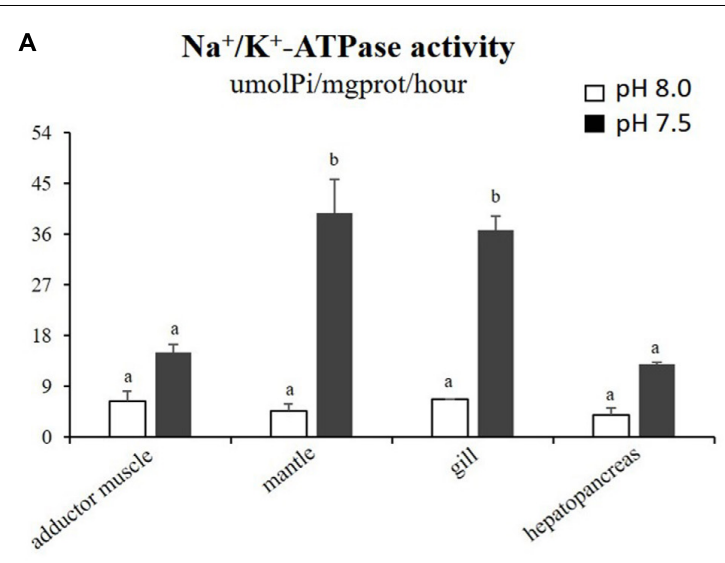

B $\quad \mathrm{Ca}^{2+} / \mathrm{Mg}^{2+}-\mathrm{ATPase}$ activity
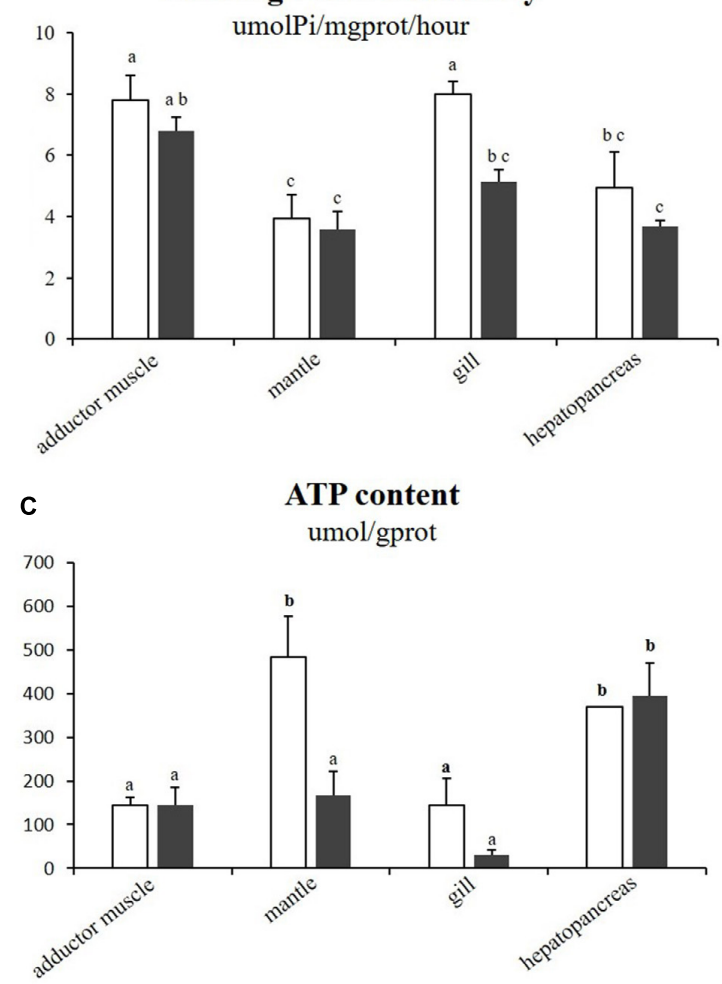

FIGURE 2 | Activities of $\mathrm{Na}^{+} / \mathrm{K}^{+}$-ATPase (A), $\mathrm{Ca}^{2+} / \mathrm{Mg}^{2+}$-ATPase (B), and ATP content (C) in four tissues of $P$. yessoensis exposed to different $\mathrm{pH}$ levels (7.5 and 8.0). Each bar represents the means \pm standard deviations $(n=6)$. Different letters indicate significant differences among different treatments $(p<0.05)$.

decrease in GPT activity suggests a reduced turnover of amino acids and protein synthesis in the hepatopancreas of $P$. yessoensis.

In the mantle of $P$. yessoensis after OA exposure, a significant decrease in the ATP level was observed. Nevertheless, the GLY content and LDH activity varied slightly, indicating that glycolysis was not affected. Interestingly, the $\mathrm{Na}^{+} / \mathrm{K}^{+}$-ATPase activity, increased significantly and sharply in the reduced-pH exposure. The enzyme $\mathrm{Na}^{+} / \mathrm{K}^{+}$-ATPase is the main motor of cellular and extracellular acid-base balance and thus acts as an important ion regulatory player, and it may be related to the capability of each species to acclimate to $\mathrm{pH}$ fluctuations (Melzner et al., 2009; Velez et al., 2016). The highly active $\mathrm{Na}^{+} / \mathrm{K}^{+}$-ATPase and massive consumption of ATP in the mantle of $P$. yessoensis suggest that a large amount of energy in the mantle was allocated to the ion regulation process to maintain the acid-base balance in the reduced-pH environment. In the mantle of the oyster C. gigas following OA-exposure $(\mathrm{pH} \sim 7.7)$ for 1 month, both the ATP content and alanine levels decreased, but the $\mathrm{Na}^{+} / \mathrm{K}^{+}$-ATPase activities were not affected. The authors suggested that alanine is transaminated to pyruvate, which together with ATP is used to build up phosphoenolpyruvate (PEP), with PEP as the substrate entering the gluconeogenetic pathway (Lannig et al., 2010). Other than the mantle, the $\mathrm{Na}^{+} / \mathrm{K}^{+}$-ATPase activities in the gill of $P$. yessoensis were also elevated after OA exposure. On the other hand, the reduced$\mathrm{pH}$ treatment decreased the $\mathrm{Ca}^{2+} / \mathrm{Mg}^{2+}$-ATPase activity without affecting the ATP content in the gills of Yesso scallops. Therefore, it is reasonable to believe that the Yesso scallop could shift the use of its ion regulation mechanism by reducing the $\mathrm{Ca}^{2+} / \mathrm{Mg}^{2+}$ ATPase activity and increasing the $\mathrm{Na}^{+} / \mathrm{K}^{+}$-ATPase activity simultaneously to regulate the acid-base balance under low $\mathrm{pH}$ exposure. A similar result has been documented in Atlantic cod (Gadus morhua), where a shift in the use of ion regulation mechanisms occurred toward enhanced $\mathrm{Na}^{+} / \mathrm{H}^{+}$-exchange and $\mathrm{HCO}^{3}$ - transport at high $\mathrm{PCO}_{2}(2200 \mu \mathrm{atm})$, paralleled by higher $\mathrm{Na}^{+} / \mathrm{K}^{+}$-ATPase activities, which did not affect the total gill energy consumption and left the whole animal energy budget unaffected (Kreiss et al., 2015).

Reactive oxygen species production is an important internal defense mechanism in bivalves such as Mytilus edulis, Cerastoderma edule, and Ensis siliqua (Wootton et al., 2003; Terahara and Takahashi, 2008). When the ROS content exceeds the antioxidant capacity, the excess ROS may lead to cell oxidative damages, such as DNA damage, membrane lipid damage and enzyme inactivation (Cheng et al., 2004a,b). Increasing ROS content and active peroxidase activities after low $\mathrm{pH}$ exposure have been reported in $M$. coruscus, C. ariakensis, and C. gigas (Bouilly et al., 2006; Gagnaire et al., 2006; Donaghy et al., 2009; Wang et al., 2016; Wu et al., 2016). In the current study, exposure to reduced-pH seawater led to high ROS production in the gill and hepatopancreas of $P$. yessoensis. The gill plays a vital role in respiration, and the hepatopancreas is a major organ for metabolism. These two organs have been shown to be sensitive to environmental stress in bivalves (Farcy et al., 2009; Lockwood et al., 2010). The high ROS content indicates that the oxidative stress occurred in the gill and hepatopancreas of Yesso scallops.

The levels of LPO, SOD, and CAT enzyme activities have been used as biomarkers to assess oxidative stress (Livingstone, 2001; Soldatov et al., 2007; Velez et al., 2016). In our study, the lipid peroxidation level did not change significantly in the reduced$\mathrm{pH}$ group, suggesting that the reduced-pH treatment has little effect on the lipid peroxidation. A similar result was reported in the clam, R. philippinarum (Velez et al., 2016). However, the SOD activities were elevated in the adductor muscles and hepatopancreas but decreased in the gill of $P$. yessoensis 

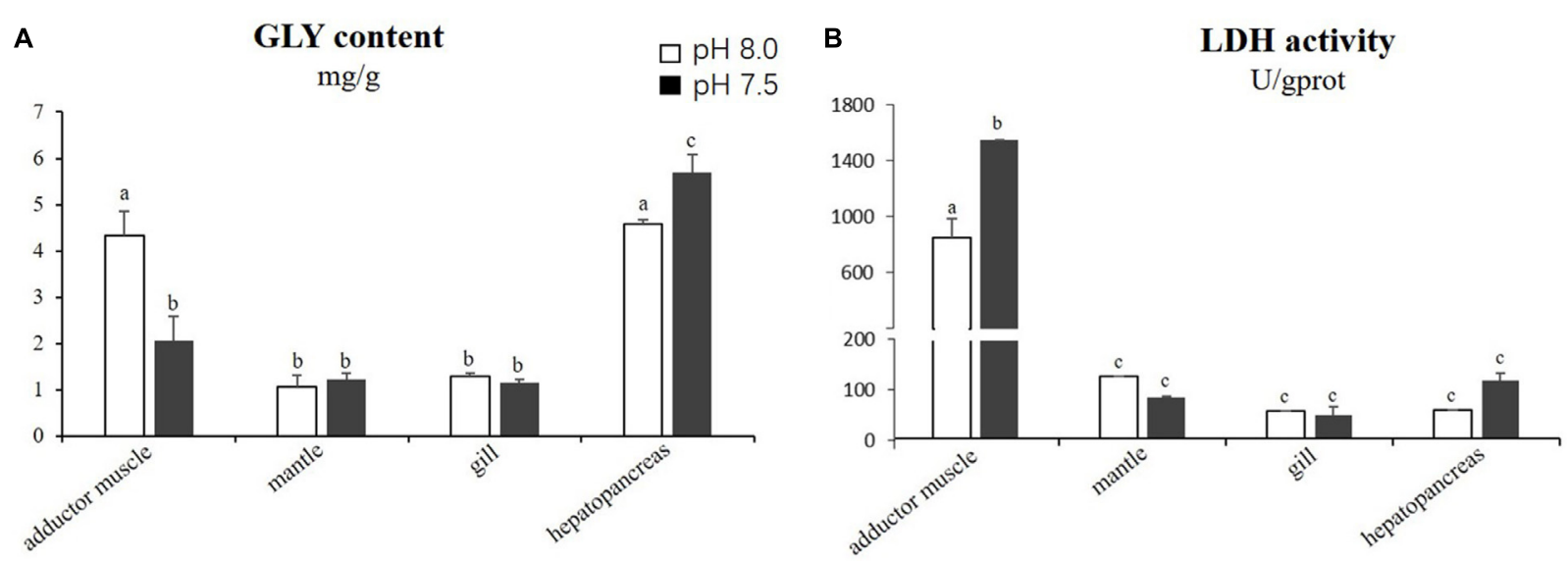

FIGURE 3 | Energy related parameters: GLY content (A) and LDH activity (B) in four tissues of $P$. yessoensis exposed to different pH levels (7.5 and 8.0). Each bar represents the means \pm standard deviations $(n=6)$. Different letters indicate significant differences among different treatments $(p<0.05)$.
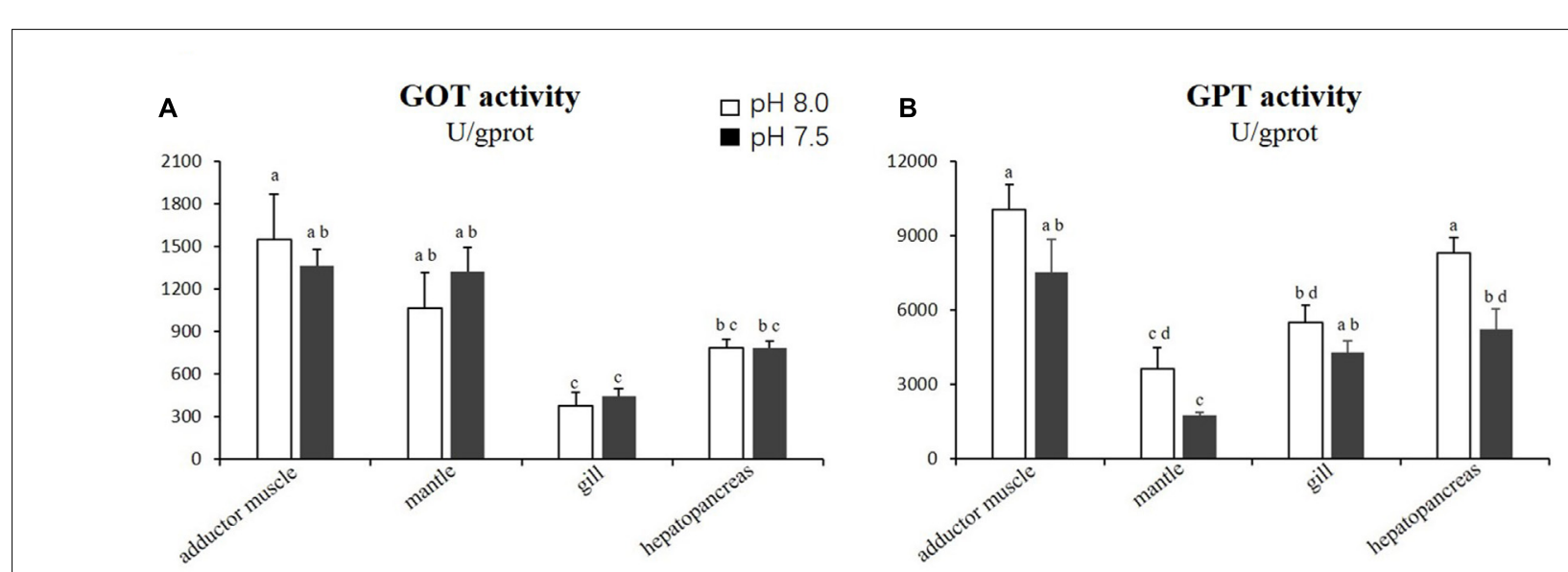

FIGURE 4 | Activities of GOT (A) and GPT (B) in four tissues of $P$. yessoensis exposed to different pH levels (7.5 and 8.0). Each bar represents the means \pm standard deviations $(n=6)$. Different letters indicate significant differences among different treatments $(p<0.05)$.

after exposure to a reduced-pH seawater. The induction of SOD, a primary scavenger of $\mathrm{O}_{2}^{-}$generated during stress condition, could inhibit the accumulation of oxygen radicals during exposure to low $\mathrm{pH}$ seawater. The weakening SOD activity in the gill tissue could indicate oxidative stress. Furthermore, the increased SOD activity resulted in a high level of $\mathrm{H}_{2} \mathrm{O}_{2}$, which should stimulate CAT activity. In our study, the activity of CAT increased in the adductor muscles, which could have been stimulated by the increased SOD activity.

\section{CONCLUSION}

The findings of the present study demonstrate that a reduction in seawater $\mathrm{pH}$ to 7.5 can potentially interfere with the energetic metabolism and antioxidant responses of scallops. Alteration of the energy demand or reserve has been observed in Yesso scallops after exposure to a reduced-pH environment. The muscle glycogen was decomposed and the activity of
$\mathrm{LDH}$ increased, leading to suppressed aerobic metabolism and increased anaerobic metabolism. At the same time, the content of glycogen increased in the hepatopancreas, indicating that scallops were able to reserve some energy when exposed to a reduced-pH environment. In addition, the high $\mathrm{Na}^{+} / \mathrm{K}^{+}$-ATPase activities in the mantle and gill suggest that energy was allocated to ion transport in maintaining the intracellular and extracellular acid-base balance. Moreover, increased oxidative stress was also induced after long-term exposure to reduced-pH seawater. Overall, our findings are useful for a better understanding of the biochemical strategies and biological limitations of scallop if the ocean acidification worsens as predicted.

\section{AUTHOR CONTRIBUTIONS}

$\mathrm{HL}, \mathrm{XH}$, and $\mathrm{ZB}$ conceived and designed the experiments, analyzed the data, and drafted the manuscript. HL, ZY, ZD, FS, SK, and ZZ performed the experiments. 


\section{FUNDING}

This research was funded by the National Natural Science Foundation of China (41676132 and U1706203), the Fundamental Research Funds for the Central Universities

\section{REFERENCES}

Anderson, D. H., and Robinson, R. J. (1946). Rapid electrometric determination of alkalinity of sea water using glass electrode. Ind. Eng. Chem. 18, 767-769. doi: 10.1021/i560160a011

Applebaum, S. L., Pan, T. C. F., Hedgecock, D., and Manahan, D. T. (2014) Separating the nature and nurture of the allocation of energy in response to global change. Integr. Comp. Biol. 54, 284-295. doi: 10.1093/icb/icu062

Barber, B. J., and Blake, N. J. (1985). Intra-Organ Biochemical transformations associated with oogenesis in the bay scallop, Argopecten irradians concentricus (Say), as Indicated by 14 C incorporation. Biol. Bull. 168, 39-49. doi: 10.2307/ 1541172

Benedetti, M., Lanzoni, I., Nardi, A., d'Errico, G., Carlo, M. D., Fattorini, D., et al. (2016). Oxidative responsiveness to multiple stressors in the key antarctic species, Adamussium colbecki: interactions between temperature, acidification and cadmium exposure. Mar. Environ. Res. 121, 20-30. doi: 10.1016/j. marenvres.2016.03.011

Beniash, E., Ivanina, A., Lieb, N. S., Kurochkin, I., and Sokolova, I. M. (2010). Elevated level of carbon dioxide affects metabolism and shell formation in oysters Crassostrea virginica. Mar. Ecol. Prog. 419, 95-108. doi: 10.3354/ meps08841

Bouilly, K., Gagnaire, B., Bonnard, M., Thomasguyon, H., Renault, T., Miramand, P., et al. (2006). Effects of cadmium on aneuploidy and hemocyte parameters in the Pacific oyster, Crassostrea gigas. Aqua. Toxicol. 78, 149-156. doi: 10.1016/j.aquatox.2006.02.028

Burow, S., and Valet, G. (1987). Flow-cytometric characterization of stimulation, free radical formation, peroxidase activity and phagocytosis of human granulocytes with 2,7-dichlorofluorescein (DCF). Eur. J. Cell Biol. 43, 128-133.

Caldeira, K., and Wickett, M. E. (2003). Oceanography: anthropogenic carbon and ocean pH. Nature 425:365. doi: 10.1038/425365a

Caldeira, K., and Wickett, M. E. (2005). Ocean model predictions of chemistry changes from carbon dioxide emissions to the atmosphere and ocean. J. Geophys. Res. 110:C09S04. doi: 10.1029/2004JC002671

Cao, R., Liu, Y., Wang, Q., Yang, D., Liu, H., Ran, W., et al. (2018). Seawater acidification reduced the resistance of Crassostrea gigas to Vibrio splendidus challenge: an energy metabolism perspective. Front. Physiol. 9:880. doi: 10.3389/ fphys.2018.00880

Carroll, N. V., Longley, R. W., and Roe, J. H. (1956). The determination of glycogen in liver and muscle by use of anthrone reagent. J. Biol. Chem. 220, 583-593.

Chen, Z., and Sun, C. (2002). Contect of ATP in RBC detect by CPK. J. Pract. Med. Tech. 9, 908-909.

Cheng, W., Fengming, J., and Chen, J. C. (2004a). The immune response of Taiwan abalone Haliotis diversicolor supertexta and its susceptibility to Vibrio parahaemolyticus at different salinity levels. Fish Shellfish Immunol. 16, 295306. doi: 10.1016/S1050-4648(03)00111-6

Cheng, W., Hsiao, I. S., Hsu, C.-H., and Chen, J.-C. (2004b). Change in water temperature on the immune response of Taiwan abalone Haliotis diversicolor supertexta and its susceptibility to Vibrio parahaemolyticus. Fish Shellfish Immunol. 17, 235-243. doi: 10.1016/j.fsi.2004.03.007

Donaghy, L., Kim, B. K., Hong, H. K., Park, H. S., and Choi, K. S. (2009) Flow cytometry studies on the populations and immune parameters of the hemocytes of the Suminoe oyster, Crassostrea ariakensis. Fish Shellfish Immunol. 27, 296-301. doi: 10.1016/j.fsi.2009.05.010

Doney, S. C., Mahowald, N., Lima, I., Feely, R. A., Mackenzie, F. T., Lamarque, J., et al. (2007). Impact of anthropogenic atmospheric nitrogen and sulfur deposition on ocean acidification and the inorganic carbon system. Proc. Natl. Acad. Sci. 104, 14580-14585. doi: 10.1073/pnas.0702218104

Dupont, S., Dorey, N., and Thorndyke, M. (2010). What meta-analysis can tell us about vulnerability of marine biodiversity to ocean acidification? Estuar. Coast. Shelf Sci. 89, 182-185. doi: 10.1016/j.ecss.2010.06.013
(201562018 and 201762016), the Earmarked Fund for Modern Agro-industry Technology Research System (CARS-49), the Seed Improvement Project of Shandong Province (2017LZGC009), and the Key Research and Development Program of Shandong Province (2016ZDJQ0208).

Eruslanov, E., and Kusmartsev, S. (2010). Identification of ROS using oxidized DCFDA and flow-cytometry. Methods Mol. Biol. 594, 57-72. doi: 10.1007/9781-60761-411-1_4

Farcy, E., Voiseux, C., Lebel, J. M., and Fiévet, B. (2009). Transcriptional expression levels of cell stress marker genes in the Pacific oyster Crassostrea gigas exposed to acute thermal stress. Cell Stress Chaperones 14, 371-380. doi: 10.1007/s12192008-0091-8

Feely, R. A. (2011). “Ocean acidification, the other CO2 Problem”. Am. Fish. Soc. 3, 1-59. doi: 10.4319/lol.2011.rfeely_sdoney.5

Feely, R. A., Alin, S. R., Newton, J., Sabine, C. L., Warner, M., Devol, A., et al. (2010). The combined effects of ocean acidification, mixing, and respiration on $\mathrm{pH}$ and carbonate saturation in an urbanized estuary. Estuar. Coast. Shelf Sci. 88, 442-449. doi: 10.1016/j.ecss.2010.05.004

Feely, R. A., Doney, S. C., and Cooley, S. R. (2009). Ocean acidification: present conditions and future changes in a high- $\mathrm{CO}_{2}$ world. Oceanography 22, 36-47. doi: 10.5670/oceanog.2009.95

Feely, R. A., Sabine, C. L., Hernandez-Ayon, J. M., Ianson, D., and Hales, B. (2008). Evidence for upwelling of corrosive "acidified" water onto the continental shelf. Science 320, 1490-1492. doi: 10.1126/science.1155676

Freitas, R., Marchi, L. D., Bastos, M., Moreira, A., Velez, C., Chiesa, S., et al. (2017). Effects of seawater acidification and salinity alterations on metabolic, osmoregulation and oxidative stress markers in Mytilus galloprovincialis. Ecol. Indic. 79, 54-62. doi: 10.1016/j.ecolind.2017.04.003

Gagnaire, B., Frouin, H., Moreau, K., Thomasguyon, H., and Renault, T. (2006). Effects of temperature and salinity on haemocyte activities of the Pacific oyster, Crassostrea gigas (Thunberg). Fish Shellfish Immunol. 20, 536-547. doi: 10.1016/ j.fsi.2005.07.003

Gazeau, F., Parker, L. M., Comeau, S., Gattuso, J. P., O'connor, W. A., Martin, S., et al. (2013). Impacts of ocean acidification on marine shelled molluscs. Mar Biol. 160, 2207-2245. doi: 10.1007/s00227-013-2219-3

Goncalves, P., Anderson, K., Thompson, E. L., Melwani, A., Parker, L. M., Ross, P. M., et al. (2016). Rapid transcriptional acclimation following transgenerational exposure of oysters to ocean acidification. Mol. Ecol. 25, 4836-4849. doi: 10.1111/mec.13808

Goncalves, P., Jones, D. B., Thompson, E. L., Parker, L. M., Ross, P. M., and Rafttos, D. A. (2017a). Transcriptomic profiling of adaptive responses to ocean acidification. Mol. Ecol. 26, 5974-5988. doi: 10.1111/mec.14333

Goncalves, P., Thompson, E. L., and Rafttos, D. A. (2017b). Contrasting impacts of ocean acidification and warming on the molecular responses of $\mathrm{CO} 2$-resilient oysters. BMC Genomics 18:431. doi: 10.1186/s12864-017-3818-z

Góth, L. (1991). A simple method for determination of serum catalase activity and revision of reference range. Int. J. Clin. Chem. 196:143. doi: 10.1016/00098981(91)90067-M

Guppy, M. (1999). Metabolic depression in animals: physiological perspectives and biochemical generalizations. Biol. Rev. Camb. Philos. Soc. 74, 1-40. doi $10.1017 /$ S0006323198005258

Haider, F., Falfushynska, H., Ivanina, A. V., and Sokolova, I. M. (2016). Effects of $\mathrm{pH}$ and bicarbonate on mitochondrial functions of marine bivalves. Comp. Biochem. Physiol. 198, 41-50. doi: 10.1016/j.cbpa.2016.03.021

Hendriks, I. E., Duarte, C. M., and Ivarez, M. (2010). Vulnerability of marine biodiversity to ocean acidification: a meta-analysis. Estuar. Coast. Shelf Sci. 86, 157-164. doi: 10.1016/j.ecss.2009.11.022

Hu, M., Li, L., Sui, Y., Li, J., Wang, Y., Lu, W., et al. (2015). Effect of $\mathrm{pH}$ and temperature on antioxidant responses of the thick shell mussel Mytilus coruscus. Fish Shell. Immunol. 46, 573-583. doi: 10.1016/j.fsi.2015. 07.025

Huang, X., Liu, Y., Liu, Z., Zhao, Z., Dupont, S., Wu, F., et al. (2018). Impact of zinc oxide nanoparticles and ocean acidification on antioxidant responses of Mytilus coruscus. Chemosphere 196, 182-195. doi: 10.1016/j.chemosphere.2017. 12.183 
Hüning, A. K., Melzner, F., Thomsen, J., Gutowska, M. A., Krämer, L., Frickenhaus, S., et al. (2013). Impacts of seawater acidification on mantle gene expression patterns of the Baltic Sea blue mussel: implications for shell formation and energy metabolism. Mar. Biol. 160, 1845-1861. doi: 10.1007/ s00227-012-1930-9

Janero, D. R. (1990). Malondialdehyde and thiobarbituric acid-reactivity as diagnostic indices of lipid peroxidation and peroxidative tissue injury. Free. Radic. Biol. Med. 9:515. doi: 10.1016/0891-5849(90)90131-2

Jensen, T. E., and Richter, E. A. (2012). Regulation of glucose and glycogen metabolism during and after exercise. J. Physiol. 590, 1069-1076. doi: 10.1113/ jphysiol.2011.224972

Kreiss, C. M., Michael, K., Lucassen, M., Jutfelt, F., Motyka, R., Dupont, S., et al. (2015). Ocean warming and acidification modulate energy budget and gill ion regulatory mechanisms in Atlantic cod (Gadus morhua). J. Comp. Physiol. 185, 767-781. doi: 10.1007/s00360-015-0923-7

Kroeker, K. J., Kordas, R. L., Crim, R., Hendriks, I. E., Ramajo, L., Singh, G. S., et al. (2013). Impacts of ocean acidification on marine organisms: quantifying sensitivities and interaction with warming. Glob. Chang. Biol. 19, 1884-1896. doi: $10.1111 /$ gcb.12179

Kroeker, K. J., Kordas, R. L., Crim, R., and Singh, G. G. (2010). Meta-analysis reveals negative yet variable effects of ocean acidification on marine organisms. Ecol. Lett. 13, 1419-1434. doi: 10.1111/j.1461-0248.2010.01518.x

Lannig, G., Eilers, S., Pörtner, H. O., Sokolova, I. M., and Bock, C. (2010). Impact of ocean acidification on energy metabolism of oyster, Crassostrea gigas - changes in metabolic pathways and thermal response. Mar. Drugs 8, 2318-2339. doi: $10.3390 / \mathrm{md} 8082318$

Lesser, M. P. (2006). Oxidative stress in marine environments: biochemistry and physiological ecology. Annu. Rev. Physiol. 68, 253-278. doi: 10.1146/annurev. physiol.68.040104.110001

Li, S., Huang, J., Liu, C., Liu, Y., Zheng, G., Xie, L., et al. (2016a). Interactive effects of seawater acidification and elevated temperature on the transcriptome and biomineralization in the pearl oyster Pinctada fucata. Environ. Sci. Technol. 50, 1157-1165. doi: 10.1021/acs.est.5b05107

Li, S., Liu, C., Huang, J., Liu, Y., Zhang, S., Zheng, G., et al. (2016b). Transcriptome and biomineralization responses of the pearl oyster Pinctada fucata to elevated CO2 and temperature. Sci. Rep. 6:18943. doi: 10.1038/srep18943

Livingstone, D. R. (2001). Contaminant-stimulated reactive oxygen species production and oxidative damage in aquatic organisms. Mar. Pollut. Bull. 42, 656-666. doi: 10.1016/S0025-326X(01)00060-1

Lockwood, B. L., Sanders, J. G., and Somero, G. N. (2010). Transcriptomic responses to heat stress in invasive and native blue mussels (genus Mytilus): molecular correlates of invasive success. J. Exp. Biol. 213, 3548-3558. doi: 10. 1242/jeb.046094

Matoo, O., Ivanina, A., Ullstad, C., Beniash, E., and Sokolova, I. (2013). Interactive effects of elevated temperature and $\mathrm{CO} 2$ levels on metabolism and oxidative stress in two common marine bivalves (Crassostrea virginica and Mercenaria mercenaria). Comp. Biochem. Physiol. 164, 545-553. doi: 10.1016/j.cbpa.2012. 12.025

Melzner, F., Göbel, S., Langenbuch, M., Gutowska, M. A., Pörtner, H. O., and Lucassen, M. (2009). Swimming performance in Atlantic Cod (Gadus morhua) following long-term (4-12 months) acclimation to elevated seawater $\mathrm{P}(\mathrm{CO} 2)$. Aqua. Toxicol. 92, 30-37. doi: 10.1016/j.aquatox.2008.12.011

Michaelidis, B., Ouzounis, C., Paleras, A., and Pörtner, H. O. (2005). Effects of long-term moderate hypercapnia on acid-base balance and growth rate in marine mussels Mytilus galloprovincialis. Mar. Ecol. Prog. 293, 109-118. doi: 10.3354/meps293109

Nardi, A., Benedetti, M., Fattorinia, D., and Regolia, F. (2018). Oxidative and interactive challenge of cadmium and ocean acidification on the smooth scallop Flexopecten glaber. Aqua. Toxicol. 196, 53-60. doi: 10.1016/j.aquatox.2018. 01.008

Orr, J. C., Fabry, V. J., Aumont, O., Bopp, L., Doney, S. C., Feely, R. M., et al. (2005). Anthropogenic ocean acidification over the twenty-first century and its impact on calcifying organisms. Nature 437, 681-686. doi: 10.1038/nature 04095

Peng, C., Zhao, X., Liu, S., Shi, W., Han, Y., Guo, C., et al. (2017). Ocean acidification alters the burrowing behaviour, $\mathrm{Ca} 2+/ \mathrm{Mg} 2+-\mathrm{ATP}$ ase activity, metabolism, and gene expression of a bivalve species, Sinonovacula constricta. Mar. Ecol. Prog. 575, 107-117. doi: 10.3354/meps12224
Perez, F. F., Fontela, M., García-Ibáñez, M. I., Mercier, H., Velo, A., Lherminier, P., et al. (2018). Meridional overturning circulation conveys fast acidification to the deep Atlantic Ocean. Nature 554, 515-518. doi: 10.1038/nature 25493

Peskin, A. V., and Winterbourn, C. C. (2000). A microtiter plate assay for superoxide dismutase using a water-soluble tetrazolium salt (WST-1). Clin. Chim. Acta 293, 157-166. doi: 10.1016/S0009-8981(99)00246-6

Pierrot, D., Lewis, E., Wallace, R., Wallace, D., Wallace, W., and Wallace, D. W. R. (2006). MS Excel Program Developed for CO2 System Calculations. Oak Ridge, TN: Carbon Dioxide Information Analysis Center.

Pörtner, H. O., and Farrell, A. P. (2008). Ecology: physiology and climate change. Science 322, 690-692. doi: 10.1126/science.1163156

Ramaswamy, M., Thangavel, P., and Panneer Selvam, N. (2015). Glutamic oxaloacetic transaminase (GOT) and glutamic pyruvic transaminase (GPT) enzyme activities in different tissues of Sarotherodon mossambicus (Peters) exposed to a carbamate pesticide, carbaryl. Pestic. Sci. 55, 1217-1221. doi: 10.1002/(SICI)1096-9063(199912)55:12<1217::AID-PS78>3.0.CO;2-G

Reitman, S., and Frankel, S. (1957). A colorimetric method for the determination of serum glutamic oxalacetic and glutamic pyruvic transaminases. Am. J. Clin. Pathol. 28, 56-63. doi: 10.1093/ajcp/28.1.56

Ries, J. B., Cohen, A. L., and McCorkle, D. C. (2009). Marine calcifiers exhibit mixed responses to CO2-induced ocean acidification. Geology 37, 1131-1134. doi: 10.1130/G30210A.1

Sabine, C. L., Feely, R. A., Gruber, N., Key, R. M., Lee, K., Bullister, J. L., et al. (2004). The oceanic sink for anthropogenic CO2. Science 305, 367-371. doi: 10.1126/science. 1097403

Shumway, S. E., and Parsons, G. J. (2006). Scallops: Biology, Ecology and Aquaculture. Amsterdam: Elsevier.

Soldatov, A. A., Gostiukhina, O. L., and Golovina, I. V. (2007). Antioxidant enzyme complex of tissues of the bivalve Mytilus galloprovincialis lam. under normal and oxidative-stress conditions: a review. Appl. Biochem. Microbiol. 43, 621-628. doi: 10.1134/S0003683807050092

Somero, G. N. (2010). The physiology of climate change: how potentials for acclimatization and genetic adaptation will determine 'winners' and 'losers'. J. Exp. Biol. 213, 912-920. doi: 10.1242/jeb.037473

Stocker, T. (2013). “IPCC, 2013: Climate Change 2013," in The Physical Science Basis. Contribution of Working Group I to the Fifth Assessment Report of the Intergovernmental Panel on Climate Change, eds T. F. Stocker, D. Qin, G.K. Plattner, M. Tignor, S. K. Allen, J. Boschung, (New York, NY: Cambridge University Press)

Strahl, J., Dringen, R., Schmidt, M. M., Hardenberg, S., and Abele, D. (2011). Metabolic and physiological responses in tissues of the long-lived bivalve Arctica islandica to oxygen deficiency. Comp. Biochem. Physiol. 158, 513-519. doi: 10.1016/j.cbpa.2010.12.015

Terahara, K., and Takahashi, K. G. (2008). Mechanisms and immunological roles of apoptosis in molluscs. Curr. Pharm. Des. 14, 131-137. doi: 10.2174/ 138161208783378725

Thomsen, J., and Melzner, F. (2010). Moderate seawater acidification does not elicit long-term metabolic depression in the blue mussel Mytilus edulis. Mar. Biol. 157, 2667-2676. doi: 10.1007/s00227-010-1527-0

Uthicke, S., Momigliano, P., and Fabricius, K. E. (2013). High risk of extinction of benthic foraminifera in this century due to ocean acidification. Sci. Rep. 3:1769. doi: 10.1038/srep01769

Velez, C., Figueira, E., Soares, A. M., and Freitas, R. (2016). Combined effects of seawater acidification and salinity changes in Ruditapes philippinarum. Aquat. Toxicol. 176, 141-150. doi: 10.1016/j.aquatox.2016. 04.016

Wang, Q., Cao, R., Ning, X., You, L., Mu, C., Wang, C., et al. (2016). Effects of ocean acidification on immune responses of the Pacific oyster Crassostrea gigas. Fish Shellfish Immunol. 49, 24-33. doi: 10.1016/j.fsi.2015. 12.025

Weeks, L. E., and Johnson, J. H. (1977). Lactate dehydrogenase determination method. U.S. Patent No 4,006,061. St. Louis, MO: Monsanto Company.

Wittmann, A. A., and Pörtner, H. (2013). Sensitivities of extant animal taxa to ocean acidification. Nat. Clim. Chang. 3, 995-1001. doi: 10.1038/ NCLIMATE1982

Wootton, E. C., Dyrynda, E. A., and Ratcliffe, N. A. (2003). Bivalve immunity: comparisons between the marine mussel (Mytilus edulis), the edible cockle 
(Cerastoderma edule) and the razor-shell (Ensis siliqua). Fish Shellfish Immunol. 15, 195-210. doi: 10.1016/S1050-4648(02)00161-4

Wootton, J. T., Pfister, C. A., and Forester, J. D. (2008). Dynamic patterns and ecological impacts of declining ocean $\mathrm{pH}$ in a high-resolution multi-year dataset. Proc. Natl. Acad. Sci. 105, 18848-18853. doi: 10.1073/pnas.0810079105

Wu, F., Lu, W., Shang, Y., Kong, H., Li, L., Sui, Y., et al. (2016). Combined effects of seawater acidification and high temperature on hemocyte parameters in the thick shell mussel Mytilus coruscus. Fish Shellfish Immunol. 56, 554-562. doi: 10.1016/j.fsi.2016.08.012

Zhai, W., Zhao, H., Zheng, N., and Xu, Y. (2012). Coastal acidification in summer bottom oxygen-depleted waters in northwestern-northern Bohai Sea from June to August in 2011. Chin. Sci. Bull. 57, 1062-1068. doi: 10.1007/s11434-0114949-2

Zhao, X., Guo, C., Han, Y., Che, Z., Wang, Y., Wang, X., et al. (2017a). Ocean acidification decreases mussel byssal attachment strength and induces molecular byssal responses. Mar. Ecol. Prog. Ser. 565, 67-77. doi: 10.3354/ meps11992
Zhao, X., Shi, W., Han, Y., Liu, S., Guo, C., Fu, W., et al. (2017b). Ocean acidification adversely influences metabolism, extracellular $\mathrm{pH}$ and calcification of an economically important marine bivalve. Tegillarca granosa. Mar. Environ. Res. 125, 82-89. doi: 10.1016/j.marenvres.2017. 01.007

Conflict of Interest Statement: The authors declare that the research was conducted in the absence of any commercial or financial relationships that could be construed as a potential conflict of interest.

Copyright $\odot 2019$ Liao, Yang, Dou, Sun, Kou, Zhang, Huang and Bao. This is an open-access article distributed under the terms of the Creative Commons Attribution License (CC BY). The use, distribution or reproduction in other forums is permitted, provided the original author(s) and the copyright owner(s) are credited and that the original publication in this journal is cited, in accordance with accepted academic practice. No use, distribution or reproduction is permitted which does not comply with these terms. 